Review article

\title{
Psychological Health amidst COVID-19: A Review of existing literature in the Indian Context
}

\author{
Jaya Shukla $^{\text {a,*, Ram Manohar Singh }}{ }^{\mathrm{b}}$ \\ ${ }^{\text {a }}$ Department of Humanities and Social Sciences, Indian Institute of Technology, Roorkee (IIT-Roorkee), India \\ ${ }^{\mathrm{b}}$ Department of Humanities and Social Sciences, Indian Institute of Technology, Roorkee (IIT-Roorkee), Uttarakhand, 247667, India
}

\section{A R T I C L E I N F O}

\section{Keywords:}

Anxiety

Depression

India

Mental health

Pandemic

\begin{abstract}
A B S T R A C T
The COVID-19 pandemic has emerged as a global health crisis. As of now, the total confirmed cases have exceeded 50 million and total deaths more than 1 million across the world. Such widespread diseases in the past have been associated with a surge in mental health disturbances. In this backdrop, the present review article pertains to discuss the overall impact of COVID-19 pandemic on mental health by synthesizing the existing literature from India, using PRISMA technique. The articles have been retrieved from Google scholar, NCBI and PubMed database. The result obtained on synthesizing the literature indicates that lockdown (home confinement) and social distancing as a measure to mitigate the outbreak of disease have affected physical and mental well-being. There has been an increase in the prevalence of anxiety and depressive disorders due to sustained stress related to COVID-19. It has led to a medico-socio-economic crisis around the world. The pandemic continues to evolve with several countries experiencing multiple waves due to continuous mutations in the virus. Hence, it is essential to carefully observe and monitor the impact of COVID-19 on the onset and progression of poor mental health.
\end{abstract}

\section{Introduction}

It is more than one year that the world entered into a crisis which has caused unprecedented damage to the human race. COVID-19 originated as a cluster of unexplained symptoms and aetiology that caused severe damage to respiratory system. ${ }^{1}$ Due to its rapid transmission, in a sequential phase, World Health Organization categorised it as Public-Health-Emergency of International-Concern (January 30, 2020) and then as a pandemic (March 11,2020). ${ }^{1}$ However, it is not the first time that an outbreak has been termed as a pandemic. Upon looking at the history of outbreaks since the beginning of 21st century i.e. 2000, world has witnessed many life-threatening diseases. While Ebola, Middle East Respiratory Syndrome (MERS), Severe Acute Respiratory Syndrome (SARS), H7N9, H5N1 were categorised as epidemics, H1N1 which originated in 2009 was a pandemic declared by World Health Organization. ${ }^{2}$ A disease is declared a pandemic when it transcends international boundaries and spread rapidly in community. ${ }^{3}$ More specifically, influenza pandemic arises when a novice influenza virus spreads across the globe, and people do not have immunity against it. ${ }^{3}$ COVID-19 is one such influenza pandemic that has not only taken a toll on physical health but the scar it has created over mental health is also unprecedented. Overall, the pandemic has led to a medico-socio-economic crisis around the world. ${ }^{3}$

The relation of pandemic with mental health is not a novel feature observed during COVID-19 outbreak. There has been evidence of PostTraumatic Stress Disorder (PTSD) among people during the Ebola outbreak. Similarly, HIV, which continues to pose a threat to the lives of people, has been associated with higher incidences of mental health issues. ${ }^{3}$ WHO has also warned the counties to be vigilant in the possible and definite spike in people's mental health issues during and post-pandemic. It has also acknowledged that the mitigation measures such as social distancing, isolation, quarantine, and lockdown to contain the spread of the COVID-19 has led to a rise in mental health issues in people, especially the vulnerable section of society. ${ }^{4}$ India, which lies in the strata of lower-middle-income countries ${ }^{5}$ has an insufficient resource allocation in the health sector. ${ }^{1}$ Nearly $1.6 \%$ of India's GDP goes into health. ${ }^{6}$ According to a report by World Health Organization, around $20 \%$ of Indian population was predicted to suffer from some form of mental disorder by the end of year $2020 .{ }^{4}$ It also stated that less than 4000 mental health experts are available in India. ${ }^{4}$ With such a

\footnotetext{
* Corresponding author. Uttarakhand, 247667, India.

E-mail addresses: jayas.iitr@gmail.com (J. Shukla), rmsingh@hs.iitr.ac.in (R. Manohar Singh).
} 
meagre resource, it becomes difficult for a vast country like India to simultaneously protect its citizens' physical and mental health. Attention, care, and action towards mental health usually take a backseat when the major fight is against infectious disease with limited resources. ${ }^{4}$ The economic slowdown induced by mitigation measures has only acted as a pinch of salt in the current crisis. The current recession has been forecasted as a major global economic crisis post 'the great depression' by International Monetary Fund. ${ }^{7}$ Due to these social and financial concerns, it becomes all the more important to observe the mental health impact of COVID-19 on Indian population.

Due to the current economic slowdown triggered by extended lockdown, social distancing, and isolation, psychologists have raised concern over possible rise in serious anxiety, mental problems, suicidal tendencies, fits of anger, alcoholism, and eccentric behavioural patterns in people and further result into an 'epidemic of despair'. ${ }^{8}$ As pay cuts and job losses have become a common phenomenon in the past few months, those in unorganized sector are at greater risk of developing mental illnesses due to their ordeal with COVID-19 and occupational crisis at the same time. ${ }^{9}$ During the lockdown, India witnessed a surge in reverse migration and its profound impact would be visible on mental health in due course of time as the pandemic unfolds itself. ${ }^{10}$ Thus, a chain of negative emotional and cognitive responses has been associated with COVID-19. Along with the adverse impact on physical health, it has become a potent cause for the current surge in mental health dysfunctions like depression, anxiety, stress, panic, and psychosomatic issues. ${ }^{9}$

Continuous attempts are being made by researchers worldwide to understand the correlations and strategies to cater to the psychological needs of different sections of society. Indian government resorted to complete lockdown, one of the harshest measures to limit the spread of the virus. Being a developing country with already a mental health disease burden of around 7\%, which has been projected to reach $20 \%$ by the end of year 2020 by WHO, ${ }^{11}$ provides researchers an impetus to investigate the existing psychological health conditions. Thus, various investigations are being conducted on psychological health of diverse populations which can serve as a guide to frame interventions suitable for them. The current systematic review was intended to understand how the pandemic has impacted the development and maintenance of anxiety, depression, and other psychosomatic disorders by using PRISMA technique. ${ }^{12}$

\section{Methodology}

The present article is a systematic review which intends to collate crux of the existing literature on mental health issues being witnessed by diverse populations during the COVID-19 pandemic in India. A search on google scholar, NCBI and PubMed database was undertaken using keywords 'COVID 19', 'mental-health,' 'psychology,' 'anxiety,' 'migrants,' 'healthcare workers,' 'depression,' 'stress,' 'suicide', 'India' in different permutation and combination (such as COVID-19 and Anxiety in India, COVID-19 and Depression in India, COVID-19 and psychological effects).

The Exclusion criteria were- Studies dealing with other epidemics and pandemics, examining physical symptoms of COVID-19, and drug therapy related to the treatment of COVID-19.

The Inclusion criteria were- Studies dealing with the impact of COVID-19 on psychological health, published in the English language with full text available, and specifically in the Indian context. The literature also included the information available on formal websites of WHO, and Ministry of Health and Family Welfare, Government of India and news reports on mental health during pandemic. The literature included articles from March 2020 to November 2020.

Keeping this in mind, 102 literature were retrieved via a literature search of various databases. After removing the duplicates, 82 articles were retained for preliminary review. On reviewing these citations, 42 papers had to be excluded as they were conducted outside India and related solely to physical health resilience and government assistance in preventing the spread of COVID-19. Another 16 had to be kept outside the purview of the current study as they were associated with other epidemics such as Ebola, HIV, and tuberculosis. The remaining 24 articles were included in the present review (procedure depicting the selection of articles shown in Fig. 1). Out of these 24 articles, only 10 articles were empirical in nature i.e. they were original research, 10 were commentary, and 4 were letters to the editor. The 10 original studies have been reported in Table 1 . There was variation in the sample size of the empirical studies. Most of the studies were conducted as an online-based survey with appropriate sample size (sample size ranges from 200 to 1537).

\section{Result and discussion}

A systematic review was conducted by briefly summarizing the salient themes from the selected publications. Three broad themes were identified in the review- (1) Empirical studies reporting on mental health dysfunction in general and specific population; (2) Literature addressing impact of pandemic on vulnerable sections of the population especially Migrant workers and Women; (3) Commentaries associated to incidences of suicide.

Empirical studies reporting on mental health dysfunction in general and specific population- Seven studies observed the occurrence of mental health dysfunction in the general Indian population, ${ }^{13-19}$ two addressed mental health issues in professionals working in healthcare, ${ }^{1,20}$ and one dealt with those suspected to be infected with COVID-19 and kept in quarantine. ${ }^{21}$ The findings of these studies are summarized in Table 1.

Findings reveal that mental health problems like anxiety, stress, and depression were frequently reported. The female gender, being in younger age group, and fear of losing job was associated with higher rates of depression and anxiety. A study by Kochhar et al. in 2020 revealed that People reported disturbances in duration and quality of sleep due to fear of getting infected. There were higher instances of depression, anxiety, and stress in young adults possibly because of uncertainty about job, career and feeling of lack of control. ${ }^{13-16}$ Majumdar et al., 2020 had reported that there was a rise in complaints of somatic discomfort. The participants which comprised of office workers and students complained discomfort in various parts of body such as upper back, neck, shoulders, and knees. The probable reasons behind this rise in somatic symptoms during lockdown were physical inactivity, lack of routine in life, increased exposure to electronic gadgets such as mobile phone and laptop. Taking Healthcare workers into account, it was found that moderate to high level of stress was prevalent in healthcare workers. Anxiety was inversely associated with duration of service as the longer the duration of being in the service, the lesser was the anxiety in the current situation. ${ }^{1,20}$ Education level also played a role in predicting depressive symptoms. ${ }^{1}$ The doctors reported lesser depressive symptoms than those Healthcare workers who had diploma or degree in nursing possibly because nurses have longer duration of exposure with patients. ${ }^{1,20}$ A study on depression and perception of stigma in people admitted in quarantine revealed that participants felt mild depression and around $95 \%$ of them perceived no stigma against them post quarantine. ${ }^{21}$ This might have happened due to the demographic characteristics as the sample consisted of only those people who were economically well-off and lived in metro-cities. ${ }^{21}$

Literature addressing impact of pandemic on Vulnerable sections of the population especially migrant workers and women- Ten publications $^{9-11,19,22-27}$ have identified vulnerable populations based on the pre-existing social condition and the interventions needed to protect them. The scope of present paper for vulnerable group is only for migrant workers and women.

Impact of pandemic on mental health of migrant workersThough migrant workers play an essential role in India's growth, there is no permanent authority to address their grievances. ${ }^{22}$ They not only live with poverty, inadequate wages, overcrowded with poor housing 


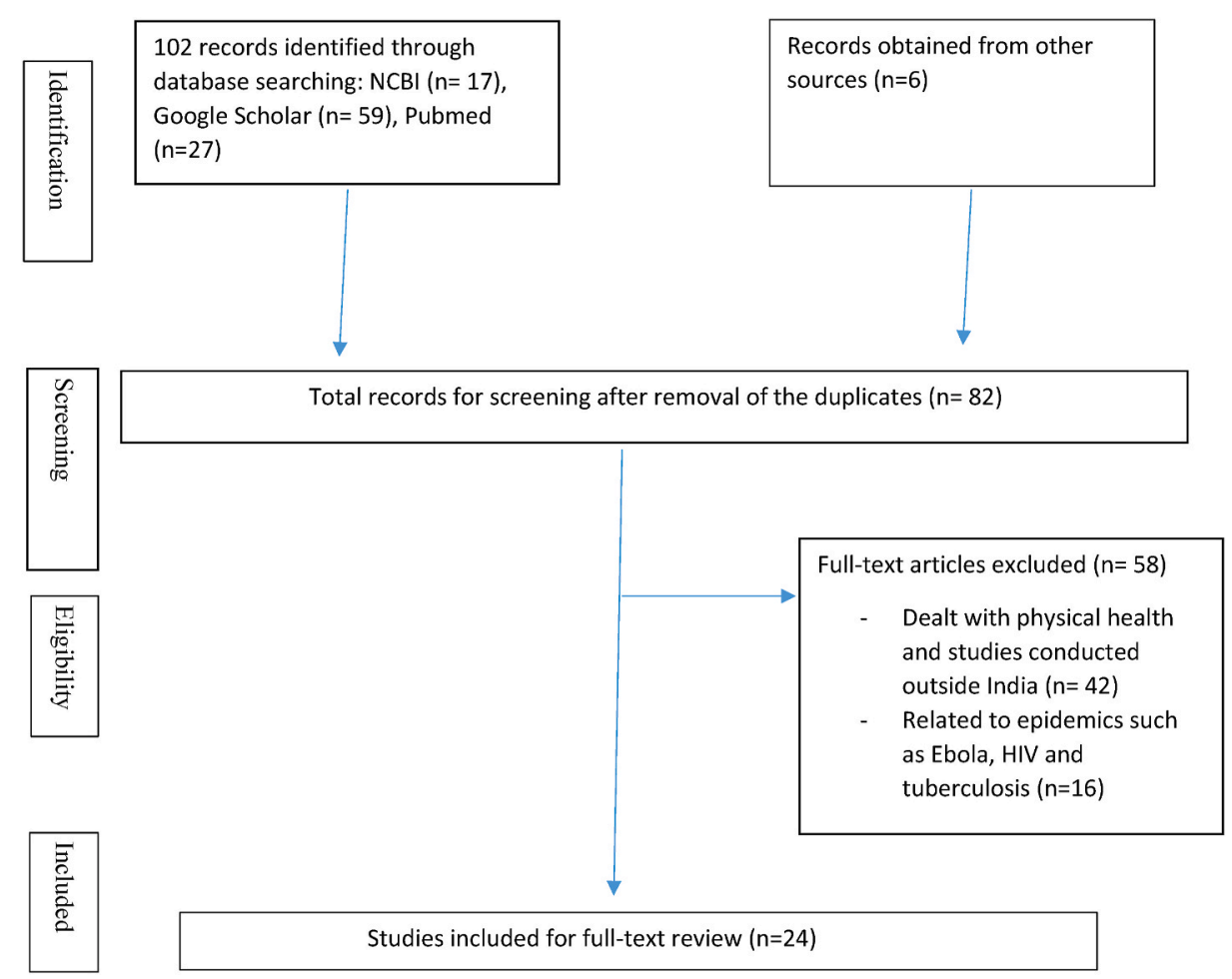

Fig. 1. Preferred Reporting Items for Systematic Reviews and Meta-Analyses (PRISMA) figure representing the procedure undertaken for Review.

conditions but are also subjected to harsh discrimination due to the differences in their languages, culture, and appearance. ${ }^{10}$ There has been an association of social inequalities like poverty, gender, education, income with common mental health disorders. ${ }^{9,10}$ As the aetiologies of mental disorders range from biological, social, and environmental factors, the pandemic has acted as a trigger in exacerbating mental health crises in these marginalized sections of society. Due to complete curb on movement, migrant workers reported rise in anxiety, stress, and panic symptoms. As they were less educated, it was difficult for them to understand the containment measures such as hand hygiene, social distancing, and use of mask. ${ }^{10}$ Moreover, According to a report by Government of India, Internal migrant workforces faced great deal of anxieties and fears after the outbreak and required psycho-social support. ${ }^{10}$ Remarkably, their anxiety and stress were not merely due to the fear of infection from COVID-19 but due to other concerns such as the uncertainty regarding length of lockdown, impatience to see their family, fear of not being paid and abandoned by their employer, and thoughts about negligence concerning other health problems of their family members. ${ }^{23}$ These factors, in turn, caused panic situation, and anxieties in them. ${ }^{22,23}$ Other than these issues, substance abuse remains one of the most common conditions among migrant workers. Their concerns during the period of lockdown also included the inability to procure substances such as liquor and tobacco. ${ }^{10}$ They even reported withdrawal symptoms such as nausea, anxiety, and insomnia. ${ }^{23}$ It has also been reported that because migrant workers have lost their source of income due to complete lockdown, there might be a rise in suicide in the near future due to joblessness and economic hardships. ${ }^{25}$ The government officials also realized the need to address mental health-related challenges, and thus, many telehealth consultation services were started. $^{23}$

Impact of pandemic on mental health of women- The impacts of COVID-19 on various aspects of life like health, economy, and social protection have exacerbated for women simply by virtue of their sex. The gains made for bringing gender equality through various global programmes of United Nations Organization are at risk of being rolled back. ${ }^{25}$ Women across the world have been at the receiving end of violence. Moreover, Indian society, which is primarily patriarchal, has a high prevalence of domestic abuse. ${ }^{19}$ The extended period of lockdown has increased domestic abuse, and exposure to violence has been known to worsen victims' mental health. ${ }^{26}$ Studies conducted on women during the pandemic revealed that they reported a higher level of stress and anxiety than men. ${ }^{19,26}$ The probable reason for women showing an increase in anxiety and stress was the social structure of Indian society. There is a skewed gender division in household chores in Indian society, which got further amplified by the extended lockdown. Even the National Mental Health Survey in 2016 reported that women show higher anxiety than men. ${ }^{26}$ World Health Organization in 2020, raised its concern over the increased violence on women and children during the lockdowns. ${ }^{11}$ It has issued guidelines to safeguard the mental health of people during COVID-19, particularly emphasizing on women, children, and service providers. ${ }^{27}$

Commentary and correspondence related to incidences of suicide- Suicide has been a significant challenge for India even before the pandemic hit us. ${ }^{28}$ Moreover, epidemics are always related to increased incidences of suicide across the world. ${ }^{29}$ There has been an abrupt rise in suicide cases since the outbreak took place. ${ }^{24,28-31}$ As the pandemic has hit the psychological health of the general population, there is a higher probability of rise in incidences of suicide. The in-depth analysis of newspaper reports related to suicide reveals that fear and anxiety related to contracting the infection, misinterpreting fever as COVID-19, and videos filled with unreliable information on social media were the main reasons. ${ }^{29}$ Other factors like loss of employment, increased family disputes due to more prolonged home confinement, pre-existing medical or mental illness acted as precipitating factors in suicide. ${ }^{31}$ High suicide rates reported among young adults in the age group of 15-35 years shift the attention towards rampant social media usage, making them more prone to be victims of infodemic. ${ }^{29}$ Hanging is the most commonly adopted method for suicide. ${ }^{29}$ Therefore, people should be vigilant towards the information being shared by social media. The government of India and World Health Organization has been actively disseminating information on the pandemic regarding staying calm and positive during the current crisis. ${ }^{32-34}$ 
Table 1

Studies reporting on mental health dysfunction in general and specific population.

\begin{tabular}{|c|c|c|c|c|}
\hline Author & Population considered & Methodology & Tools & Findings \\
\hline $\begin{array}{l}\text { Kazmi et al. } \\
\text { (2020) }\end{array}$ & General population( $\mathrm{n}=1000)$ & Online based survey & DASS-21, Demographic profile & $\begin{array}{l}\text { - Higher anxiety and stress in age range } \\
\text { (21-25); } \\
\text { - Mild anxiety in age group } 41 \text { and above; } \\
\text { - Depression more in } 15-35 \text { age range }\end{array}$ \\
\hline $\begin{array}{l}\text { Kochhar et al. } \\
\text { (2020) }\end{array}$ & Gen. population $(\mathrm{n}=992)$ & $\begin{array}{l}\text { Online survey, Self- } \\
\text { rated questionnaire }\end{array}$ & $\begin{array}{l}\text { fear of contacting virus, helplessness, post } \\
\text { quarantine stressors linked to work, stigma } \\
\text { and boredom }\end{array}$ & $\begin{array}{l}\text { - Negative correlation between fear of } \\
\text { infection and sleep; } \\
\text { - Positive correlation between covid updates } \\
\text { and anxiety; } \\
\text { - Helplessness and fatigue in } 12 \% \text { due to } \\
\text { diminished social contact; } \\
\text { - } 11 \% \text { engaged in hobbies suggested by WHO; } \\
\text { - 55\% trouble sleeping; } 79 \% \text { variation in } \\
\text { eating pattern }\end{array}$ \\
\hline $\begin{array}{l}\text { Desai et al., } \\
2020\end{array}$ & Gen. $(\mathrm{n}=1537)$ & Cross sectional survey & $\begin{array}{l}\text { Patient Health Questionnaire, } \\
\text { General Anxiety Disorder, } \\
\text { Demographic details }\end{array}$ & $\begin{array}{l}\text { - Depression more in Females; } \\
\text { - Depressive symptoms more in School and UG } \\
\text { students than other occupation; } \\
\text { - } 47 \% \text { prevalence of depression and } 41.5 \% \\
\text { anxiety } \\
\text { - Higher anxiety reported by } 21-50 \text { age group. }\end{array}$ \\
\hline $\begin{array}{l}\text { Mishra and } \\
\text { Verma } 2020\end{array}$ & Gen population $(\mathrm{n}=354)$ & $\begin{array}{l}\text { Cross sectional online } \\
\text { survey }\end{array}$ & $\begin{array}{l}\text { DASS-21,Demographic details including } \\
\text { Binge drinking and substance abuse }\end{array}$ & $\begin{array}{l}\text { - } 25 \% \text { moderate to severe depression } \\
\text { - } 28 \% \text { anxious } \\
\text { - } 11.6 \% \text { stressed } \\
\text { - } 15 \% \text { indulged into binge drinking } \\
\text { - Fear of losing job associated with depression } \\
\text { and anxiety. }\end{array}$ \\
\hline $\begin{array}{l}\text { Majumdar } \\
\text { et al., } 2020\end{array}$ & $\begin{array}{l}\text { Gen population ( } \mathrm{n}=203 \\
\text { corporate employees and } 325 \\
\text { university students) }\end{array}$ & $\begin{array}{l}\text { Online questionnaire } \\
\text { survey }\end{array}$ & $\begin{array}{l}\text { Epworth sleepiness scale } \\
\text { CES-D } \\
\text { Nordic questionnaire for somatic discomfort }\end{array}$ & $\begin{array}{l}\text { - Rise in health comorbidities among } \\
\text { employees and students. } \\
\text { - Reduced duration and quality of sleep among } \\
\text { office workers } \\
\text { - Sleep duration increased in students with } \\
34 \% \text { admitting excessive sleepiness } \\
\text { - Depressive symptoms increased from } 1.97 \% \\
\text { to } 14.7 \% \text { in employees and from } 7 \% \text { to } 30 \% \\
\text { among students }\end{array}$ \\
\hline $\begin{array}{l}\text { Rehman et al., } \\
2020\end{array}$ & General population $(n=403)$ & Online based survey & $\begin{array}{l}\text { Family Affluence scale, } \\
\text { DASS- } 21\end{array}$ & $\begin{array}{l}\text { - Mild stress, moderate anxiety and mild } \\
\text { depression reported in people } \\
\text { - No gender difference in reported anxiety, } \\
\text { stress, and depression } \\
\text { - Negative correlation between family } \\
\text { affluence and mental health issues. }\end{array}$ \\
\hline $\begin{array}{l}\text { Gopal et al., } \\
2020\end{array}$ & General population $(\mathrm{n}=159)$ & $\begin{array}{l}\text { Longitudinal study } \\
\text { using web based survey }\end{array}$ & GAD-7, PHQ-4,Single item for stress & $\begin{array}{l}\text { - Rise in anxiety, stress and symptoms of } \\
\text { depression with passage of time in lockdown } \\
\text { - Higher rate of increase in anxiety and stress } \\
\text { symptoms in females. }\end{array}$ \\
\hline $\begin{array}{l}\text { Wilson et al., } \\
2020\end{array}$ & $\begin{array}{l}\text { Healthcare professionals }(\mathrm{n}= \\
\text { 433) }\end{array}$ & $\begin{array}{l}\text { Cross sectional online } \\
\text { based survey }\end{array}$ & $\begin{array}{l}\text { Cohens Perceived Stress Scale, Public Health } \\
\text { Questionnaire-9, General Anxiety Disorder-7 }\end{array}$ & $\begin{array}{l}\text { - Moderate and High level of stress in } 81 \% \\
\text { - Moderately severe and severe depression in } \\
10.6 \% \\
\text { - Moderate and severe anxiety in } 17.7 \% \\
\text { - High concern about spread of infection to } \\
\text { family in } 78 \%\end{array}$ \\
\hline $\begin{array}{l}\text { Gupta and } \\
\text { Sahoo. } 2020\end{array}$ & Healthcare employees $(n=1124)$ & $\begin{array}{l}\text { Cross sectional online } \\
\text { based survey }\end{array}$ & Hospital Anxiety and Depression Scale & $\begin{array}{l}\text { - } 37 \% \text { anxiety symptoms } \\
\text { - Women nurses between } 20 \text { and } 35 \text { years with } \\
\text { less than } 10 \text { years of experience were more } \\
\text { anxious } \\
\text { - Doctors and whose Service duration more } \\
\text { than } 20 \text { years were less anxious. } \\
\text { - Education level predicted depressive } \\
\text { symptoms with less educated feeling more } \\
\text { depressed. }\end{array}$ \\
\hline $\begin{array}{l}\text { Sharma et al., } \\
2020\end{array}$ & $\begin{array}{l}\text { People admitted in quarantine ( } \mathrm{n} \\
=62 \text { ) }\end{array}$ & Cross sectional survey & $\begin{array}{l}\text { Semi structured interview, CES-D scale } \\
\text { (Centre for Epidemiological Studies- } \\
\text { Depression Scale) }\end{array}$ & $\begin{array}{l}\text { - } 62.9 \% \text { participants felt mild depression } \\
\text { - } 87 \% \text { confident to overcome the current } \\
\text { situation with medical support } \\
\text { - } 93 \% \text { felt society to have no stigma against } \\
\text { them post quarantine }\end{array}$ \\
\hline
\end{tabular}

\section{Conclusion}

Though a very few observational studies are presented in this review, it shows that the COVID-19 pandemic has led to various mental health concerns among general population, health care professionals, and vulnerable sections of society. The literature also suggests that there has been rise in cases of suicide since lockdown. As the pandemic continues to unfold, the rise in mental health issues is a challenging task for mental health professionals and Government of India. The mental health issues presented in above literature needs to be further studied and steps to be taken accordingly. The World Health Organization has explicitly raised its concern over the possible mental health issues among the population, which needs to be addressed on a mission mode. As the number of people contracting the virus continues to rise, it brings a challenge and an opportunity to the government and the health care professionals at large. The challenges in the form of social barriers are identified in the 
current review and an opportunity to implement the recommendations of international organizations. There is a need to follow a multipronged approach at the individual, society, and government level. Thus, to contain the aftermath of COVID-19, mental health needs to be addressed with the same vigor as physical health is addressed. Development of need-based interventions while taking cultural sensitivity into account would prove instrumental in protecting the mental health of the most vulnerable group.

\section{Declaration of competing interest}

We have no conflict of interest to disclose.

\section{Acknowledgement}

This research did not receive any specific grant from funding agencies in the public, commercial, or not-for-profit sectors.

\section{References -}

1 Gupta S, Sahoo S. Pandemic and mental health of the front-line healthcare workers: a review and implications in the Indian context amidst COVID-19 [Internet] Gen Psychiatr. 2020 Oct;33(5). https://doi.org/10.1136/gpsych-2020-100284. Available from: Pandemic and mental health of the front-line healthcare workers: a review and implications in the Indian context amidst COVID-19 (nih.gov).

2 Kerkhove MD, Ferguson NM. Epidemic and Intervention Modelling: A Scientific Rationale for Policy Decisions? Lessons from the 2009 Influenza Pandemic [Internet]. Bulletin of the World Health Organization; 2012. Available from: Bulletin of the World Health Organization (scielosp.org).

3 Phin NF. Living Forwards, Understanding Backwards [Internet]. Bulletin of the World Health Organization; 2011. Available from: SciELO - Public Health - Living forwards, understanding backwards Living forwards, understanding backwards (scielosp.org).

4 Roy A, Singh AK, Mishra S, Chinnadurai A, Mitra A, Bakshi O. Mental health implications of COVID-19 pandemic and its response in India [Internet] Int $J$ Soc Psychiatr. 2020 Sep;1. https://doi.org/10.1177/0020764020950769. Available from: Mental health implications of COVID-19 pandemic and its response in India (nih.gov).

5 World Bank Blogs. World Bank Data Team [Internet]. 2019. New Country classifications by income level: 2019-2020; Available from: New country classifications by income level: 2019-2020 (worldbank.org).

6 Ministry of Finance. Economic Survey Volume II [Internet]. Ministry of Finance, Government of India; 2020. Available from: epreface_vol2.pdf (indiabudget.gov.in).

7 International Monetary Fund Blog. The Great Lockdown: Worst Economic Downturn since the Great Depression [Internet]. IMF Blog; 2020. Available from: The Great Lockdown: Worst Economic Downturn Since the Great Depression - IMF Blog.

8 Narayanan MK. The Spectre of a Post-COVID-19 World [Internet]. The Hindu; 2020. Apr 4;Available from: The spectre of a post-COVID-19 world - The Hindu.

9 Choudhari R. COVID 19 pandemic: mental health challenges of internal migrant workers of India [Internet] Asian J Psychiatr. $2020 \mathrm{Jun}$. https://doi.org/10.1016/j. ajp.2020.102254, 54. Available from: COVID 19 pandemic: Mental health challenges of internal migrant workers of India - ScienceDirect.

10 Singh OP. Mental health of migrant laborers in COVID-19 pandemic and lockdown: challenges ahead [Internet] Indian J Psychiatr. 2020 May;62(3). Available from: Mental health of migrant laborers in COVID-19 pandemic and lockdown: Challenges ahead Singh O P - Indian J Psychiatry DOI: 10.4103/psychiatry.IndianJPsychiatry_ 422_20.

11 World Health Organization. WHO; 2020. Mental Health and Psychosocial Considerations during the COVID-19 Outbreak [Internet]. 2020. Mar 18. Available from: . Microsoft Word - Mental health considerations 2020-02-14e en 19MARCH2020_marissa.docx (who.int).

12 Liberati A, Altman DG, Tetzlaff J, et al. The PRISMA statement for reporting systematic reviews and meta-analyses of studies that evaluate health care interventions: explanation and elaboration. J Clinical epidemiology. 2009 Oct;62(10). https://doi.org/10.1016/j.jclinepi.2009.06.006. Available from: The PRISMA statement for reporting systematic reviews and meta-analyses of studies that evaluate health care interventions: explanation and elaboration - ScienceDirect.

13 Kazmi SS, Hasan K, Talib S, Saxena S. COVID-19 and lockdown: a study on the impact on mental health. SSRN. 2020 Apr. https://doi.org/10.2139/ssrn.3577515. Available from: COVID-19 and Lockdwon: A Study on the Impact on Mental Health by Syed Sajid Husain Kazmi, Dr Kashif Hasan, Sufia Talib, Sagar Saxena :: SSRN.

14 Kochhar AS, Bhasin R, Kochhar GK, et al. Lockdown of 1.3 billion people in India during Covid-19 pandemic: a survey of its impact on mental health [Internet] Asian $J$ Psychiatr. 2020 Jun. https://doi.org/10.1016/j.ajp.2020.102213 (54). Available from: Lockdown of 1.3 billion people in India during Covid-19 pandemic: A survey of its impact on mental health (nih.gov).

15 Desai M, Khan A, Kulkarni R, Hegde B. The Psychological Impact of COVID-19 and the Subsequent Social Isolation on the General Population of Karnataka, India. Jidhealth
[Internet]; 2020 Sep, 3(Special 1)190-5. Available from: https://jidhealth.com/ index.php/jidhealth/article/view/51 DOI: 10.47108/jidhealth.Vol3.IssSpecial1.51.

16 Verma S, Mishra A. Depression, anxiety, and stress and socio-demographic correlates among general Indian public during COVID-19 [Internet] Int J Soc Psychiatr. 2020 Jun;66(8):756-762. https://doi.org/10.1177/0020764020934508. Available from: Depression, anxiety, and stress and socio-demographic correlates among general Indian public during COVID-19 - Shankey Verma, Aditi Mishra, 2020 (sagepub.com).

17 Majumdar P, Biswas A, Sahu S. COVID-19 pandemic and lockdown: cause of sleep disruption, depression, somatic pain, and increased screen exposure of office workers and students of India [Internet] Chronobiol Int. 2020 Jul;37(8):1191-1200. https:// doi.org/10.1080/07420528.2020.1786107. Available from: COVID-19 pandemic and lockdown: cause of sleep disruption, depression, somatic pain, and increased screen exposure of office workers and students of India (tandfonline.com).

18 Rehman U, Shahnawaz MG, Khan NH, et al. Depression, anxiety and stress among Indians in times of Covid-19 lockdown [Internet] Community Ment Health J. 2020 Jun;57(1):42-48. https://doi.org/10.1007/s10597-020-00664-x. Available from: Depression, Anxiety and Stress Among Indians in Times of Covid-19 Lockdown (springer.com).

19 Gopal A, Sharma AJ, Subramanyam MA. Dynamics of psychological responses to COVID-19 in India: a longitudinal study [Internet] PloS One. 2020 Oct;15(10). https://doi.org/10.1371/journal. pone.0240650. Available from: Dynamics of psychological responses to COVID-19 in India: A longitudinal study (plos.org) DOI.

20 Wilson W, Raj JP, Rao S, et al. Prevalence and predictors of stress, anxiety, and depression among healthcare workers managing COVID-19 pandemic in India: a nationwide observational study [Internet] Indian J Psychol Med. 2020 Jul;42(4): 353-358. https://doi.org/10.1177/0253717620933992. Available from: Prevalence and Predictors of Stress, anxiety, and Depression among Healthcare Workers Managing COVID-19 Pandemic in India: A Nationwide Observational Study (sagepub.com).

21 Sharma S, Bansal R, Parashar P, Ahmad S, Kumar A. Stress and depression among people admitted in a COVID 19 quarantine centre of north India [Internet] Subharti $J$ of Interdisciplinary Research. 2020 Aug;3(2):33-37. Available from: Article-7.pdf (subharti.org).

22 Lakhan R, Kosgi S, Agrawal A, Sharma M. Letter to editor: Re:"Primary care physician's approach for mental health impact of COVID-19": case of migrant workers mental health [Internet] J Fam Med Prim Care. 2020 Oct;9(10):5394-5396. https://doi.org/10.4103/jfmpc.jfmpc 1716 20. Available from: JFamMedPrimaryCare9105394-5591445_153154.pdf(jfmpc.com).

23 Chander R, Murugesan M, Ritish D, et al. Addressing the mental health concerns of migrant workers during the COVID-19 pandemic: an experiential account [Internet] Int J Soc Psychiatr. 2020 Jun:1-4. https://doi.org/10.1177/0020764020937736. Available from: Addressing the mental health concerns of migrant workers during the COVID-19 pandemic: An experiential account (sagepub.com).

24 Nelson VM. Suicide prevention India foundation; 2020. Available from: http://www.rfi. $\mathrm{fr} / \mathrm{en} /$ international/20200514-mental-illness-suicides-on-the-rise-in-india-during covid-19-lockdown.

25 [Internet]. UN Women. Gender Equality: Women's Rights in Review 25 Years after Beijing. UN Women; 2020. Available from: Gender equality: Women's rights in review 25 years after Beijing | Digital library: Publications | UN Women Headquarters.

26 Nigam S. COVID-19, Lockdown, and Violence against Women in Homes [Internet]. SSRN; 2020 Apr. https://doi.org/10.2139/ssm.3587399. Available from:.

27 Kumar A, Rajshekharan K. COVID 19 and its mental health consequences [Internet] J Ment Health. 2020 Apr. https://doi.org/10.1080/09638237.2020.1757052 DOI: 10.1080/09638237.2020.1757052. Available from:.

28 Shoib S, Nagendrappa S, Grigo O, Rehman S, Ransing R. Factors associated with COVID-19 outbreak-related suicides in India [Internet] Asian J Psychiatry. 2020 Jun. https://doi.org/10.1016/j.ajp.2020.102223, 53. Available from: Factors associated with COVID-19 outbreak-related suicides in India - ScienceDirect.

29 Goyal K, Chauhan P, Chhikara K, Gupta P, Singh MP. Fear of COVID 2019: first suicidal case in India! [Internet] Asian J Psychiatry. 2020 Mar. https://doi.org/ 10.1016/j.ajp.2020.101989, 49. Available from: Fear of COVID 2019: First suicidal case in India ! (nih.gov).

30 Rajkumar RP. COVID-19 and mental health: a review of the existing literature [Internet] Asian J Psychiatry. 2020 Aug:52. https://doi.org/10.1016/j. ajp.2020.102066. Available from: COVID-19 and mental health: A review of the existing literature - ScienceDirect.

31 Thakur V, Jain A. COVID 2019-suicides: a global psychological pandemic [Internet] Brain Behav Immun. 2020 Aug;88:952-953. https://doi.org/10.1016/j. bbi.2020.04.062. Available from: COVID 2019-suicides: A global psychological pandemic (nih.gov).

32 Ministry of Health and Family Welfare. Mental Health in Times of COVID-19 PandemicGuidance for General Medical and Specialised Mental Health Care Settings [Internet]. Ministry of Health and Family Welfare Government of India; 2020 Sep 15. Available from: https://www.mohfw.gov.in/pdf/COVID19Final2020ForOnline9July2020.pdf.

33 [Internet]. Govt to Use 108 Helpline for Mental Health Counselling. The New Indian Express; 2020 Apr 12. Available from: Govt to use 108 helpline for mental health counselling- The New Indian Express.

34 [Internet]. Government Launches Helpline for Mental Health Issues during Lockdown. The Economic Times; 2020 Mar 29. Available from: Government launches helpline for mental health issues during lockdown - The Economic Times (indiatimes.com). 